\title{
Single Nucleotide Polymorphisms within Calcineurin-Encoding Genes are Associated with Response to Aerobic Training in Han Chinese Males
}

\author{
${ }^{1}$ Rong-mei Xu, ${ }^{2}$ Tao Lu, ${ }^{2}$ Lingxian Yan, ${ }^{1}$ Qinghua Song ${ }^{*}$ \\ ${ }^{1}$ The Center of Physical Health, Henan Polytechnic University, Jiaozuo 454000, Henan Province, China. ${ }^{2}$ The Lab of \\ Human Body Science, Henan Polytechnic University, Jiaozuo 454000, Henan Province, China.
}

\begin{abstract}
Calcineurin, which functions in calcium signaling, is expressed in skeletal and cardiac muscle and has been linked to sensitivity to muscle strength training. It is also proposed to contribute to individual aerobic endurance. To investigate the relationship between calcineurin-encoding genes and aerobic endurance traits, 126 young-adult Han Chinese males were enrolled in an aerobic exercise training study. Participants were genotyped for polymorphisms within the 5 genes (PPP3CA, PPP3CB, PPP3CC, PPP3R1 and PPP3R2) encoding calcineurin using restriction fragment length polymorphism polymerase chain reaction (PCR-RFLP) or matrix-assisted laser desorption ionization time-of-flight mass spectrometry (MALDI-TOF MS). Participants underwent 18 weeks of aerobic exercise training (running). Before and after the training period, maximal oxygen uptake (VO2max) and $12 \mathrm{~km} / \mathrm{h}$ running economy were measured. Statistical analyses were performed using chi-square test and analysis of variance. The baseline value of VO2max was significantly associated with rs3804423 and rs2850965 loci in the PPP3CA gene $(\mathrm{P}<0.05)$. The training responsiveness of VO2max was significantly associated with the rs3804358 locus in PPP3CA and the rs4671887 locus in PPP3R1 $(\mathrm{P}<0.05)$. The training responsiveness of running economy was significantly associated with rs3739723 in PPP3R2 $(\mathrm{P}<0.05)$. These findings indicate that polymorphisms within the calcineurin-encoding genes may partially explain individual differences in response to aerobic training.
\end{abstract}

KEY WORDS: Calcineurin, Running Economy, $V_{2 \max }$ Polymorphism.

\section{INTRODUCTION}

The serine/threonine phosphatase calcineurin $(\mathrm{CN})$ is widely distributed in eukaryotes, is directly regulated by calcium ions in the process of cellular signal transduction, and plays a role in dephosphorylation (1). During exercise training, calcium ions flow activates $\mathrm{CN}$ to cause calcium ions fluctuations and thereby plays a role as an active receptor in muscle contraction $(2,3)$.
Calcium ions can transmit neuromuscular signals and thereby trigger related gene expression, and $\mathrm{CN}$ can activate the expression of many genes, including calcium ions uptake genes and energy metabolism genes (4). The $\mathrm{CN}$-mediated signal transduction pathway is one of the most important pathways for inducing calcium ions; it causes calcium ion signals to interact jointly with the regulatory mechanisms of other messengers and regulate the functions of

*. Corresponding Author:

Qinghua Song

E-mail: sqhhn2014@163.com 
cells (5). As such, it is found in cells of various tissues, including brain, skeletal muscle, cardiac, and cardiovascular endothelium cells, as well as T lymphocytes (6).

According to experiments by Nordsborg et al. (2010), exercise-induced increases in $\mathrm{Na}(+), \mathrm{K}$ (+) pump alpha1 and beta1 mRNA expression in trained subjects are more pronounced after highthan after moderate- and low-intensity exercise, and $\mathrm{Ca}^{2+}$ regulates alphal mRNA expression in oxidative muscles via $\mathrm{Ca}{ }^{(2+)} /$ calmodulindependent protein kinase $(\mathrm{CaMK})$ and calcineurin signalling pathways (7). In an investigation on the causal link between the limitation of myofibre transitions and modulation of calcineurin activity, an exercise of both high frequency and amplitude (swimming) or low frequency and amplitude (running) can induce an initial activation followed by the inhibition of calcineurin (8). These studies indicate a role for $\mathrm{CN}$ in response to exercise. Given its interaction with calcium, presence in muscle tissues, and fluctuations during exercise, $\mathrm{CN}$ is proposed to correlate with individual differences in response to aerobic training.

$\mathrm{CN}$ is composed of a regulatory subunit $(\mathrm{CnB})$ and a catalytic subunit $(\mathrm{CnA}) \cdot \mathrm{CnB}$ includes two isomers, $\mathrm{CnB} 1$ and $\mathrm{CnB} 2$, which are encoded, respectively, by PPP $3 R 1$ (protein phosphatase 3 , regulatory subunit $B$, alpha) on chromosome 2p16-p15 and PPP3R2 (protein phosphatase 3 , regulatory subunit $B$, beta) on chromosome $9 \mathrm{q} 31$. CnA includes three isomers, $\mathrm{CnA} \alpha, \mathrm{CnA} \beta$, and $\mathrm{CnA} \gamma$, which are encoded, respectively, by $P P P 3 C A$ (protein phosphatase 3 , catalytic subunit, alpha isozyme) on chromosome 4q21-q24, $P P P 3 C B$ (protein phosphatase 3 , catalytic subunit, beta isozyme) on chromosome 10q21-q22, and PPP3CC (protein phosphatase 3, catalytic subunit, gamma isozyme) on chromosome $8 \mathrm{p} 21.2$ (9). Insertion/deletion polymorphisms within the PPP3R1 promoter region have been associated with left ventricular hypertrophy and the sensitivity to training for muscular strength (10, 11). Previous reports have also indicated that some variants produce $\mathrm{CN}$ with different activity levels and are correlated with better exercise endurance in elite athletes $(12,13)$. However, few studies have investigated the correlation between polymorphisms within the genes encoding $\mathrm{CN}$ and response to aerobic training in a general population.

In this study, single nucleotide polymorphisms (SNPs) within the five genes encoding $\mathrm{CN}, P P P 3 C A, P P P 3 C B, P P P 3 C C$, $P P P 3 R 1$ and $P P P 3 R 2$, were investigated for a potential role in aerobic training response. Specifically, genotypes were compared against maximal oxygen uptake $\left(\mathrm{VO}_{2} \max \right)$ and running economy (RE) to explore the correlation between $\mathrm{CN}$ variants and individual differences in response to aerobic training.

\section{MATERIALS AND METHODS}

Participants. This prospective study recruited 126 male first-year students from the School of Physical Education of Henan Polytechnic University, China. All participants were healthy individuals of Han population born in Henan province. The mean age, height, and weight for these participants were $19.0 \pm 1.6$ years, $171.2 \pm 6.1 \mathrm{~cm}$, and $59.98 \pm 6.61 \mathrm{~kg}$, respectively. Potential participants who had a training history or long-term endurance exercise were excluded, which was recounted by themselves. In this study, informed consent was obtained from all participants, ethical approval was obtained by the Henan Polytechnic University, and the study was conducted within the principles set out in the declaration of Helsinki.

Aerobic Exercise and Physiological Indexes. All participants underwent 5000-meter steady aerobic running outside on a track, 3 times per week, for a total of 18 weeks, as in a prior report (13). Before 5000-meter aerobic running, 2-week adaptive training was performed with 1000-meter and 3000-meter running at the first and second week. Then, only general flexibility exercises were performed. During training, all participants lived together in an apartment and had unified food. During each aerobic running, each participant wore a Polar Sport Tester (PST; Polar Company) that determine exercise intensity controlled via the heart rate (HR) corresponding to the individual anaerobic threshold (VT) and was monitored $\left(\mathrm{VT}_{\mathrm{HR}} \pm 3\right)$ with a Polar Sport Tester (Polar Electro Inc., Lake Success, NY, USA). For the first 10 weeks, the intensity of training was targeted at $95 \%$ of individual $\mathrm{VT}_{\mathrm{HR}}$; for the last 8 
weeks, subjects were asked to run at $105 \%$ of their individual $\mathrm{VT}_{\mathrm{HR}}$. The running economy (RE, $12 \mathrm{~km} / \mathrm{h}$, reported in $\mathrm{VO} 2$ in $\mathrm{L} / \mathrm{min}$ ) and maximal aerobic capacity (VO2max, L/min) were also measured by using an open circuit spirometry (Parvomedics, Sandy, UT, USA) during a continuous incremental protocol on a motorized treadmill (Erich Jaeger Treadmill E5, German) (14). The oxygen consumption was measured on JAEGER Oxygen Analyzer (Germany).

Selection and Genotyping of SNPs. The total lengths of PPP $3 C A, P P P 3 C B, P P P 3 C C$,
PPP3R1, and PPP3R2 were $323.8 \mathrm{~kb}, 59.14 \mathrm{~kb}$, $100 \mathrm{~kb}, 73.66 \mathrm{~kb}$, and $3.385 \mathrm{~kb}$, respectively. They were extended by $2 \mathrm{~kb}$ toward the upstream direction and $2 \mathrm{~kb}$ toward the downstream direction. SNPs of these 5 genes for Han Chinese people in Beijing were downloaded from www.hapmap.org, and 55 tag SNPs were selected using the Tagger program of the Haploview software version 4.0. Of these, 33 were located in $P P P 3 C A, 4$ were located in $P P P 3 C B, 12$ were located in $P P P 3 C C, 3$ were located in $P P P 3 R 1$, and 3 were located in PPP3R2. See Table 1.

Table 1 The calcineurin-encoding genes for SNP analysis in this study

\begin{tabular}{|c|c|c|c|c|c|c|c|c|}
\hline \multirow[t]{2}{*}{ Gene } & \multirow[t]{2}{*}{ Position } & \multirow[t]{2}{*}{ dbSNP ID } & \multirow[t]{2}{*}{ Locus } & \multirow[t]{2}{*}{ Alleles } & \multirow[t]{2}{*}{$\begin{array}{c}\text { Allele } \\
\text { frequency* }\end{array}$} & \multirow[t]{2}{*}{$\begin{array}{c}\text { Allele } \\
\text { frequency\# }\end{array}$} & \multicolumn{2}{|c|}{$\begin{array}{c}\mathrm{H}-\mathrm{W} \\
\text { equilibrium }\end{array}$} \\
\hline & & & & & & & $\chi^{2}$ & $P$ \\
\hline \multicolumn{9}{|l|}{ PPP3CA } \\
\hline 1 & 10240141 & rs13123962 & Intron 1 & $\mathrm{C} / \mathrm{T}$ & C:0.37 & C:0.38 & 0.40 & 0.48 \\
\hline 2 & 102405174 & rs2850972 & Intron 1 & $\mathrm{C} / \mathrm{T}$ & C:0.37 & C:0.32 & 0.51 & 0.42 \\
\hline 3 & 102180970 & rs2251238 & Intron 10 & $\mathrm{C} / \mathrm{T}$ & C:0.17 & C:0.18 & 1.34 & 0.21 \\
\hline 4 & 102430245 & rs2850355 & Intron 1 & $\mathrm{C} / \mathrm{T}$ & $\mathrm{T}: 0.47$ & $\mathrm{~T}: 0.48$ & 0.71 & 0.28 \\
\hline 5 & 102397986 & rs2850965 & Intron 1 & $\mathrm{G} / \mathrm{T}$ & G:0.11 & G:0.12 & 0.13 & 0.85 \\
\hline 6 & 102303778 & rs4478191 & Intron 2 & $\mathrm{C} / \mathrm{T}$ & $\mathrm{T}: 0.33$ & T:0.26 & 1.72 & 0.15 \\
\hline 7 & 102259114 & rs12639641 & Intron 2 & $\mathrm{C} / \mathrm{T}$ & C:0.39 & C:0.31 & 5.31 & 0.01 \\
\hline 8 & 102322069 & rs10050301 & Intron 2 & $\mathrm{~A} / \mathrm{G}$ & A: 0.38 & A:0.36 & 0.11 & 0.87 \\
\hline 9 & 102299759 & rs2695215 & Intron 2 & $\mathrm{~A} / \mathrm{C}$ & A:0.24 & A:0.32 & 2.61 & 0.10 \\
\hline 10 & 102459770 & rs2850371 & Intron 1 & $\mathrm{~A} / \mathrm{G}$ & G:0.46 & G:0.47 & 2.98 & 0.09 \\
\hline 11 & 102284612 & rs 10516472 & Intron 2 & $\mathrm{~A} / \mathrm{G}$ & G:0.10 & G:0.06 & 0.61 & 0.39 \\
\hline 12 & 102198890 & rs1405686 & Intron 10 & $\mathrm{C} / \mathrm{T}$ & $\mathrm{T}: 0.13$ & T:0.17 & 1.21 & 0.21 \\
\hline 13 & 102365194 & rs2851007 & Intron 1 & $\mathrm{~A} / \mathrm{G}$ & A:0.26 & A:0.35 & 2.76 & 0.08 \\
\hline 14 & 102332047 & rs2659509 & Intron 2 & $\mathrm{~A} / \mathrm{C}$ & C:0.38 & C:0.28 & 0.59 & 0.40 \\
\hline 15 & 102253020 & rs2732512 & Intron 2 & $\mathrm{C} / \mathrm{T}$ & C:0.23 & C:0.20 & 0.61 & 0.42 \\
\hline 16 & 102303638 & rs2695220 & Intron 2 & $\mathrm{~A} / \mathrm{G}$ & G:0.14 & 0.17 & 1.43 & 0.22 \\
\hline 17 & 102241124 & rs3804358 & Intron 3 & $\mathrm{C} / \mathrm{G}$ & C:0.13 & C:0.12 & 0.45 & 0.49 \\
\hline 18 & 102260259 & rs6820738 & Intron 2 & $\mathrm{G} / \mathrm{T}$ & G:0.32 & G:0.37 & 0.40 & 0.51 \\
\hline 19 & 102260644 & rs6532920 & Intron 2 & $\mathrm{~A} / \mathrm{G}$ & A:0.49 & A: 0.45 & 0.09 & 0.72 \\
\hline 20 & 102317089 & rs17030887 & Intron 2 & $\mathrm{C} / \mathrm{T}$ & C:0.23 & C:0.24 & 0.09 & 0.76 \\
\hline 21 & 102303638 & rs2659544 & Intron 2 & $\mathrm{C} / \mathrm{G}$ & G:0.14 & G:0.18 & 2.43 & 0.11 \\
\hline 22 & 102298759 & rs2695214 & Intron 2 & $\mathrm{~A} / \mathrm{G}$ & C:0.39 & C:0.43 & 0.10 & 0.71 \\
\hline 23 & 102303638 & rs2659510 & Intron 7 & $\mathrm{~A} / \mathrm{C}$ & G:0.24 & G:0.35 & 1.89 & 0.90 \\
\hline 24 & 102322700 & rs 17030900 & Intron 2 & $\mathrm{C} / \mathrm{G}$ & G:0.20 & G:0.23 & 0.34 & 0.51 \\
\hline 25 & 102320175 & rs 2850983 & Intron 2 & $\mathrm{~A} / \mathrm{G}$ & G:0.16 & G:0.18 & 4.71 & 0.02 \\
\hline 26 & 102454392 & rs2044041 & Intron 1 & $\mathrm{~A} / \mathrm{T}$ & A:0.11 & A:0.15 & 0.76 & 0.32 \\
\hline 27 & 102439907 & rs3789753 & Intron 1 & $\mathrm{~A} / \mathrm{G}$ & A:0.10 & A:0.15 & 0.78 & 0.31 \\
\hline 28 & 102480291 & rs17031191 & Intron 1 & $\mathrm{C} / \mathrm{T}$ & $\mathrm{T}: 0.11$ & T:0.15 & 0.01 & 0.91 \\
\hline 29 & 102406885 & rs3804423 & Intron 1 & $\mathrm{~A} / \mathrm{G}$ & A:0.11 & A:0.10 & 0.007 & 0.98 \\
\hline 30 & 102312830 & rs2659501 & Intron 2 & $\mathrm{C} / \mathrm{T}$ & $\mathrm{T}: 0.42$ & $\mathrm{~T}: 0.51$ & 1.22 & 0.21 \\
\hline 31 & 102247953 & rs931870 & Intron 3 & $\mathrm{C} / \mathrm{G}$ & C:0.30 & C:0.29 & 0.27 & 0.59 \\
\hline 32 & 102327937 & rs2850988 & Intron 2 & $\mathrm{~A} / \mathrm{G}$ & A:0.30 & A:0.36 & 0.03 & 0.89 \\
\hline 33 & 102221146 & rs3804357 & Intron 7 & $\mathrm{~A} / \mathrm{C}$ & A:0.23 & 0.26 & 0.12 & 0.71 \\
\hline 34 & 102442409 & rs1031034 & intron 1 & $\mathrm{G} / \mathrm{T}$ & $\mathrm{T}: 0.47$ & $\mathrm{~T}: 0.45$ & 0.09 & 0.73 \\
\hline
\end{tabular}




\begin{tabular}{|c|c|c|c|c|c|c|c|c|}
\hline \multicolumn{9}{|l|}{ РРРЗСВ } \\
\hline 35 & 74904832 & rs 3763679 & Intron 3 & $\mathrm{C} / \mathrm{T}$ & $\mathrm{T}: 0.29$ & $\mathrm{~T}: 0.28$ & 1.14 & 0.30 \\
\hline 36 & 74867057 & rs12644 & exon $14,3^{\prime}$-UTR & $\mathrm{A} / \mathrm{G}$ & A: 0.46 & $\mathrm{~A}: 0.50$ & 0.38 & 0.52 \\
\hline 37 & 74891291 & rs12245450 & Intron 9 & $\mathrm{~A} / \mathrm{C}$ & C:0.30 & C:0.32 & 0.76 & 0.39 \\
\hline \multicolumn{9}{|l|}{ РРРЗСС } \\
\hline 38 & 22442424 & rs2461483 & intron 10 & $\mathrm{C} / \mathrm{T}$ & $\mathrm{T}: 0.49$ & $\mathrm{~T}: 0.37$ & 1.76 & 0.12 \\
\hline 39 & 22376751 & rs10108011 & intron 1 & $\mathrm{~A} / \mathrm{G}$ & G:0.24 & G:0.27 & 0.35 & 0.51 \\
\hline 40 & 22361446 & rs7821470 & intron 1 & $\mathrm{C} / \mathrm{T}$ & C:0.20 & C:0.19 & 0.43 & 0.45 \\
\hline 41 & 22359385 & rs10096012 & intron 1 & $\mathrm{~A} / \mathrm{G}$ & G:0.14 & G:0.13 & 0.16 & 0.69 \\
\hline 42 & 22369931 & rs1879793 & intron 1 & $\mathrm{C} / \mathrm{T}$ & C:0.30 & $C: 0.32$ & 3.61 & 0.06 \\
\hline 43 & 22446882 & rs2449341 & intron 12 & $\mathrm{~A} / \mathrm{C}$ & C:0.34 & C:0.35 & 0.82 & 0.36 \\
\hline 44 & 22426198 & rs2461489 & intron 5 & $\mathrm{C} / \mathrm{T}$ & C:0.49 & C:0.44 & 1.41 & 0.26 \\
\hline 45 & 22430019 & rs1075534 & intron 6 & $\mathrm{~A} / \mathrm{G}$ & A:0.36 & A:0.39 & 1.76 & 0.13 \\
\hline 46 & 22375143 & rs7837713 & intron 1 & $\mathrm{C} / \mathrm{T}$ & C:0.13 & C:0.12 & 0.18 & 0.68 \\
\hline 47 & 22405456 & rs2461494 & intron 5 & $\mathrm{C} / \mathrm{T}$ & C:0.18 & $C: 0.24$ & 2.13 & 0.11 \\
\hline 48 & 22454359 & rs7430 & 3'-UTR & $\mathrm{C} / \mathrm{G}$ & $\mathrm{G}: 0.40$ & G:0.33 & 0.15 & 0.70 \\
\hline 49 & 22380522 & rs13271367 & intron 1 & $\mathrm{~A} / \mathrm{G}$ & A: 0.48 & A: 0.47 & 11.2 & $<0.01$ \\
\hline \multicolumn{9}{|l|}{ PPP3RI } \\
\hline 50 & 68330051 & rs13004394 & intron 1 & $\mathrm{C} / \mathrm{T}$ & C:0.12 & C:0.17 & 1.41 & 0.22 \\
\hline 51 & 68329099 & rs4671887 & intron 1 & $\mathrm{~A} / \mathrm{C}$ & C:0.36 & C:0.33 & 1.03 & 0.31 \\
\hline 52 & 68331452 & rs2029091 & intron 1 & $\mathrm{C} / \mathrm{T}$ & C:0.47 & C:0.49 & 0.12 & 0.71 \\
\hline
\end{tabular}

$P P P 3 R 2$

\begin{tabular}{lllllllll}
53 & 103397893 & rs1323433 & 3' near gene & A/G & A:0.33 & A:0.25 & 0.18 & 0.69 \\
54 & 103394171 & rs3739723 & exon 1, 3'-UTR & A/T & A:0.28 & A:0.22 & 0.04 & 0.82 \\
55 & 103395276 & rs1407877 & exon 1, 3'-UTR & A/G & A:0.20 & A:0.22 & 0.11 & 0.75 \\
\hline
\end{tabular}

*: Allele frequency for Chinese Han Population downloaded from Hapmap website (www.hapmap.org), \#: Allele frequency for the participants involved in the present study.

Wizard Genomic DNA Extraction Kit (Promega) was used to extract DNA from fresh blood sample $(500 \mu \mathrm{L})$. rs 12644 was analyzed using the PCR-RFLP method, while other loci were analyzed using MALDI-TOF-MS (MatrixAssisted Laser Desorption/ Ionization Time of Flight Mass Spectrometry (10). Assay Designer (Sequenom) was used to design single-base extension primers and PCR primers. DNA samples were diluted to a concentration of 5 $\mathrm{ng} / \mu \mathrm{L}$. Then, $1 \mu \mathrm{L}$ was mixed with $0.625 \mu \mathrm{L}$ of PCR buffer, $0.325 \mu \mathrm{L}$ of $25 \mathrm{mM} \mathrm{MgCl} 2,0.1 \mu \mathrm{L}$ of HotStar Taq, $1 \mu \mathrm{L}$ of $2.5 \mathrm{mM}$ dNTP, $1 \mu \mathrm{L}$ of PCR primer and $0.95 \mu \mathrm{L}$ of water, which was performed according to recommendations from manufacturers (DBI ${ }^{\circledR}$ Bioscience). Reactions were conducted in the PCR Thermal Cycler Dice (TaKaRa Biotech, TP600) using the following conditions: Initial denaturation at $94^{\circ} \mathrm{C}$ for $15 \mathrm{~min}$; and 45 cycles of denaturation at $94^{\circ} \mathrm{C}$ for $20 \mathrm{~s}$, primer annealing at $56^{\circ} \mathrm{C}$ for $30 \mathrm{~s}$ and elongation at $72^{\circ} \mathrm{C}$ for $1 \mathrm{~min}$, and extension at $72^{\circ} \mathrm{C}$ for $3 \mathrm{~min}$. After PCR amplification, the system for next reaction included $0.17 \mu \mathrm{L}$ of SAP buffer, 0.3 unit of alkaline phosphatase, and $1.53 \mu \mathrm{L}$ of water. The solution was placed at $37^{\circ} \mathrm{C}$ for $40 \mathrm{~min}$, then at $85^{\circ} \mathrm{C}$ for $5 \mathrm{~min}$ to cause enzyme inactivation. The reaction system for the single-base primer extension included $0.2 \mu \mathrm{L}$ of 10x iPLEX buffer, $0.041 \mu \mathrm{L}$ of iPLEX enzyme, $0.2 \mu \mathrm{L}$ of termination mix, $0.804 \mu \mathrm{L}$ of $10 \mu \mathrm{M}$ extension primer, and $0.755 \mu \mathrm{L}$ of water. The reaction was performed under the following conditions: $30 \mathrm{~s}$ at $94^{\circ} \mathrm{C}$; and $5 \mathrm{~s}$ at $94^{\circ} \mathrm{C}, 5 \mathrm{~s}$ at $52^{\circ} \mathrm{C}, 5 \mathrm{~s}$ at $80^{\circ} \mathrm{C}$, and $3 \mathrm{~min}$ at $72^{\circ} \mathrm{C}$, for 45 cycles. This reaction product was treated with $6 \mathrm{mg}$ of cation-exchange resin (Sequenom) and $25 \mu \mathrm{L}$ of water for suspension. MassARRAY Nanodispenser (Sequenom) was used to apply 
the genotyped samples to the spectroCHIP. MALDI-TOF MS (ABI 4800 plus, Applied Biosystems, Foster City, CA, USA) was used for analysis. The results were read by the MassARRAY RT software system (Sequenom), and the genotyping assay was completed using the MassARRAY Typer software.

Statistical Analysis. Double data entry was performed using EpiData version 3.1 to create a data bank, and logic checks were performed. SAS 9.2 (SAS Institute) was used for data analysis using chi-squared and analysis of variance (ANOVA) tests. The two-factor repeated measures ANOVA was used for the correlation between polymorphisms and initial values of endurance phenotypes and the sensitivity to training. Corrected P-values were used for multiple comparisons. The effect sizes of polymorphisms correlated with the VO2max and RE are expressed as Cohen's d (95\% CI). $\mathrm{P}<0.05$ was considered to indicate a difference was statistically significant.

\section{RESULTS}

To determine whether variants in the genes encoding calcineurin are associated with response to aerobic training, genotypes of participants were compared with various exercise measures following an 18-week aerobic training (Table 2). Because the genotype distributions of rs13271367, rs12639641, and rs2850983 did not meet Hardy-Weinberg equilibrium, these loci were not analyzed further. Additionally, because a large amount of data was generated, only statistically significant polymorphic loci are listed in Table 2. Compared to the baseline measures, the participants' $\mathrm{VO}_{2} \max$ increased, while their running economy (measured at 12 $\mathrm{km} / \mathrm{h}$ ) decreased. First, genotypes and $\mathrm{VO}_{2} \max$ were compared. After correction for multiple comparisons, rs3804423 and rs2850965 in PPP3CA were significantly correlated with pretraining value of $\mathrm{VO}_{2} \max (P<0.05)$. rs 3804358 in PPP3CA and rs4671887 in PPP3R1 were correlated with the sensitivity to training for $\mathrm{VO}_{2} \max$ and had marked genotype $\mathrm{x}$ training interaction effects; these differences were statistically significant $(P<0.05)$.

\begin{tabular}{|c|c|c|c|c|c|}
\hline SNP & $\begin{array}{c}\mathrm{VO}_{2} \mathrm{max} \\
\text { (pre-training) }\end{array}$ & $\begin{array}{c}\mathrm{VO}_{2} \text { max } \\
\text { (post-training) }\end{array}$ & $\begin{array}{c}P \\
\text { (genotype) }\end{array}$ & $\begin{array}{c}P \\
\text { (training) }\end{array}$ & $\begin{array}{c}\text { interaction } \\
\text { (genotype*training) }\end{array}$ \\
\hline \multicolumn{6}{|l|}{ РPРЗСА } \\
\hline rs2850965 & & & 0.001 & 0.042 & 0.412 \\
\hline $\mathrm{GG}(\mathrm{n}=4)$ & $3.67 \pm 0.36$ & $3.47 \pm 0.37$ & & & \\
\hline $\mathrm{GT}(\mathrm{n}=24)$ & $3.65 \pm 0.48$ & $3.76 \pm 0.49$ & & & \\
\hline \multirow[t]{2}{*}{$\mathrm{TT}(\mathrm{n}=98)$} & $3.37 \pm 0.34$ & $3.43 \pm 0.35$ & & & \\
\hline & & & 0.004 & 0.011 & 0.091 \\
\hline \multicolumn{6}{|l|}{ rs3804423 } \\
\hline $\mathrm{AA}(\mathrm{n}=5)$ & $3.36 \pm 0.43$ & $3.55 \pm 0.44$ & & & \\
\hline $\mathrm{AG}(\mathrm{n}=22)$ & $3.60 \pm 0.48$ & $3.74 \pm 0.43$ & & & \\
\hline \multirow[t]{2}{*}{$\mathrm{GG}(\mathrm{n}=99)$} & $3.39 \pm 0.37$ & $3.43 \pm 0.39$ & & & \\
\hline & & & 0.217 & 0.793 & 0.002 \\
\hline \multicolumn{6}{|l|}{ rs3804358 } \\
\hline $\mathrm{CC}(\mathrm{n}=6)$ & $3.25 \pm 0.40$ & $3.12 \pm 0.12$ & & & \\
\hline $\mathrm{CG}(\mathrm{n}=27)$ & $3.62 \pm 0.40$ & $3.52 \pm 0.35$ & & & \\
\hline $\mathrm{GG}(\mathrm{n}=93)$ & $3.41 \pm 0.39$ & $3.52 \pm 0.41$ & & & \\
\hline \multicolumn{6}{|l|}{ PPP3RI } \\
\hline rs4671887 & & & 0.514 & 0.275 & 0.004 \\
\hline$C C(n=21)$ & $3.36 \pm 0.0 .27$ & $3.34 \pm 0.31$ & & & \\
\hline $\mathrm{AC}(\mathrm{n}=49)$ & $3.50 \pm 0.40$ & $3.48 \pm 0.40$ & & & \\
\hline $\mathrm{AA}(\mathrm{n}=56)$ & $3.43 \pm 0.40$ & $3.56 \pm 0.44$ & & & \\
\hline
\end{tabular}

Note: Because of the large amount of data, for simplicity Table 2 only lists the loci that reached statistical significance. 
Genotypes and performance (response to aerobic training) in running economy were also compared. Again, the data presented in the table (Table 3 ) include only statistically significant loci. rs3739723 (PPP3R2) was correlated with the sensitivity to training for running economy and had a marked genotype $\mathrm{x}$ training interaction effect; this difference was statistically significant $(P<0.05)$.

\begin{tabular}{cccccc}
\hline \multicolumn{6}{c}{ Table 3. Single nucleotide polymorphism associated with running economy (L/min) at 12 km/h } \\
\hline SNP & $\begin{array}{c}\mathrm{RE} \\
\text { (pre-training) }\end{array}$ & $\begin{array}{c}\mathrm{RE} \\
\text { (post-training) }\end{array}$ & $\begin{array}{c}P \\
\text { (genotype) }\end{array}$ & $\begin{array}{c}P \\
\text { (training) }\end{array}$ & $\begin{array}{c}\text { interaction } \\
\text { (genotype* training) }\end{array}$ \\
\hline PPP3R2 & & & & & \\
rs3739723 & & & 0.402 & $<0.001$ & \\
AA(n=7) & $2.79 \pm 0.08$ & $2.52 \pm 0.10$ & & & \\
AT(n=41) & $2.65 \pm 0.28$ & $2.39 \pm 0.24$ & & & \\
TT(n=78) & $2.70 \pm 0.29$ & $2.50 \pm 0.27$ & & & \\
\hline
\end{tabular}

Note: Because of the large amount of data, for simplicity Table 3 only lists the locus that reached statistical significance.

RE: running economy

The effect sizes of SNPs rs2850965, rs3804423, rs3804358, rs4671887, and rs3739723 correlated with $\mathrm{VO}_{2}$ max and running economy are shown in Table 4.

\begin{tabular}{|c|c|c|c|c|c|}
\hline & rs2850965 & rs 3804423 & rs3804358 & rs4671887 & rs 3739723 \\
\hline \multicolumn{6}{|l|}{ pre- } \\
\hline $\begin{array}{c}\text { training } \\
\mathrm{aa} / \mathrm{ab}\end{array}$ & $0.01(-0.89,0.96)$ & $0.51(-0.41 .1 .48)$ & $0.82(-0.08,1.90)$ & $0.37(-0.19,0.87)$ & $0.42(-0.19,0.94)$ \\
\hline $\mathrm{aa} / \mathrm{bb}$ & $0.76(0.29,1.23)$ & $0.09(-0.35,0.53)$ & $0.32(-0.11,0.79)$ & $0.20(-0.34,0.68)$ & $0.32(-0.11,079)$ \\
\hline $\mathrm{ab} / \mathrm{bb}$ & $0.75(0.30,1.21)$ & $0.62(0.22,1.13)$ & $0.56(0.16,0.97)$ & $0.18(-0.23,0.61)$ & $0.08(-0.35,0.50)$ \\
\hline \multicolumn{6}{|l|}{$\begin{array}{l}\text { post- } \\
\text { training }\end{array}$} \\
\hline$a a / a b$ & $0.59(-0.35,1.57)$ & $0.56(-0.43,1.56)$ & $1.20(0.19,2.04)$ & $0.37(-0.20,0.94)$ & $0.42(-0.21,1.13)$ \\
\hline $\mathrm{aa} / \mathrm{bb}$ & $0.12(-0.31,0.57)$ & $0.30(-0.13,0.75)$ & $0.87(0.40,1.29)$ & $0.53(0.03,1.10)$ & $0.08(-0.40,0.57)$ \\
\hline$a b / b b$ & $0.91(0.41,1.32)$ & $0.86(0.42,1.35)$ & $0.07(-0.31,0.48)$ & $0.21(-0.22,0.65)$ & $0.48(0.04,0.91)$ \\
\hline
\end{tabular}

Note: Value is Cohen's d (95\% CI) effect size. $\mathrm{d}<0.2,0.2-0.5$, and $>0.8$ are, respectively, small, medium, and large effects. "a" refers to the low frequency of alleles, "b" refers to the high frequency of alleles.

\section{DISCUSSION}

To build on previous studies that indicated that variants in the genes encoding $\mathrm{CN}$ are associated with sensitivity to strength training (9-13), this study assessed possible associations between SNPs in the genes encoding $\mathrm{CN}$ and markers of response to aerobic training, $\mathrm{VO}_{2} \max$ and running economy. Four significant SNPs were identified as associating with initial values of $\mathrm{VO}_{2} \mathrm{max}$ or the sensitivity to training: rs2850965, rs3804423, and rs3804358 in PPP3CA and rs3739723 in PPP3R1. A fifth SNP, rs3739723 in PPP3R2, was correlated with the sensitivity to training for running economy.
The latter finding is similar to the findings of Bray et al. (15).

The $\mathrm{VO}_{2}$ max value depends on both central and peripheral factors. The central mechanism is limited by cardiac structure, function, and cardiac cell maturation. Cardiac hypertrophy also depends on the $\mathrm{CN}$ signaling pathway (16). In $\mathrm{CnA} \beta$-deficient mice, $\mathrm{CN}$ activities are lower, their hearts are smaller, and they have reduced capacity to respond to myocardial hypertrophy caused by external stimuli (17). Similarly, if mutations are introduced in $\mathrm{CnB}$ to block its phosphatase activity activated by calcium ions, then mouse vascular development is abnormal; this suggests that the $\mathrm{Ca}^{2+}-\mathrm{CN}$ signaling pathway 
functions early in vascular development and the surrounding tissues (18); in other words, $\mathrm{CN}$ can influence the cardiac structure and function. Thus, polymorphisms within the PPP $3 C A$ gene may affect the skeletal muscle. rs3739723 in the PPP3R2 gene was found in this study to be correlated with the sensitivity to training for running economy, which is a determining factor for aerobic capacity under submaximal load (19).

The peripheral mechanism of $\mathrm{VO}_{2} \max$ regulation mainly includes oxidase activity, muscle fiber types, and mitochondrial density. $\mathrm{CN}$ may participate in several of these activities. $\mathrm{CnA}$, encoded by PPP3CA, regulates $\mathrm{CN}$ expression in the skeletal muscle (20). Additionally, $\mathrm{CN}$ up-regulates slow muscle troponins in mouse myoblasts and rat soleus muscles (21). In trangenic mice with highly expressed $\mathrm{CN}$, there is an increase in the expression of myoglobins and slow muscle troponins and in GLUT4 expression in skeletal muscle (22). Thus, $\mathrm{CN}$ is proposed to regulate the expression of GLUT4. Further, $\mathrm{CN}$ has an important effect upon mitochondrial biogenesis (23, 24). Finally, a loss of skeletal muscle oxidative capacity was observed after $\mathrm{CN}$ inhibitors were orally given to organ transplant patients (25). Therefore, $\mathrm{CN}$ plays important regulatory roles in muscle function. Combined with our results, these studies indicate that $\mathrm{CN}$ may be important to determining exercise capacity.

\section{CONCLUSION}

In summary, the rs 2850965 , rs 3804423 , and rs3804358 polymorphisms within the PPP $3 C A$ gene as well as the rs4671887 polymorphism in the $P P P 3 R 1$ gene were correlated with the initial values of $\mathrm{VO}_{2} \max$ or the sensitivity to training, and the rs3739723 polymorphism in the PPP3R2 gene was correlated with the sensitivity to training for running economy. Therefore, variants of $\mathrm{CN}$-encoding genes may partly explain the individual differences in response to aerobic training.

\section{APPLICABLE REMARKS}

- The SNPs, rs 2850965 , rs 3804423 , and rs3804358 in PPP3CA and rs3739723 in PPP3Rl, were identified as associating with initial values of $\mathrm{VO}_{2}$ max or the sensitivity to training.

- The SNP, rs3739723 in PPP3R2, was correlated with the sensitivity to training for running economy.

\section{ACKNOWLEDGMENTS}

This work was supported by Science and Technology Department of Henan Province (Grant No.142700410395).

\section{REFERENCES}

1. Hardie DG. AMP-activated protein kinase: an energy sensor that regulates all aspects of cell function. Genes \& development. 2011;25(18):1895-908.

2. Bassel-Duby R, Olson EN. Signaling pathways in skeletal muscle remodeling. Annual review of biochemistry. 2006;75:19-37.

3. He ZH, Hu Y, Li YC, Bao DP, Ruiz JR, Lucia A. Polymorphisms in the calcineurin genes are associated with the training responsiveness of cardiac phenotypes in Chinese young adults. European journal of applied physiology. 2010;110(4):761-7.

4. Koulmann N, Bigard AX. Interaction between signalling pathways involved in skeletal muscle responses to endurance exercise. Pflugers Archiv : European journal of physiology. 2006;452(2):125-39.

5. Molkentin JD. Parsing good versus bad signaling pathways in the heart: role of calcineurin-nuclear factor of activated T-cells. Circulation research. 2013;113(1):16-9.

6. Schultz K, Nelson J, Vu H, editors. Quantification of the inhibition of calcineurin by protein phosphatase assay2012; Central Washington University.

7. Nordsborg NB, Kusuhara K, Hellsten Y, Lyngby S, Lundby C, Madsen K, et al. Contraction-induced changes in skeletal muscle $\mathrm{Na}+\mathrm{K}+$ pump mRNA expression - importance of exercise intensity and $\mathrm{Ca} 2+-$ mediated signalling. Acta Physiologica. 2010;198(4):487-98. 
8. Grondard C, Biondi O, Pariset C, Lopes P, Deforges S, Lecolle S, et al. Exercise-induced modulation of calcineurin activity parallels the time course of myofibre transitions. Journal of cellular physiology. 2008;214(1):126-35.

9. Huang X, Liu Y, Wang R, Zhong X, Liu Y, Koop A, et al. Two potential calmodulin-binding sequences in the ryanodine receptor contribute to a mobile, intra-subunit calmodulin-binding domain. Journal of cell science. 2013;126(Pt 19):4527-35.

10. Akhmetov, II, Linde EV, Shikhova Iu V, Popov DV, Missina SS, Vinogradoba OL, et al. [The influence of calcineurin gene polymorphism on morphofunctional characteristics of cardiovascular system of athletes]. Rossiiskii fiziologicheskii zhurnal imeni IM Sechenova / Rossiiskaia akademiia nauk. 2008;94(8):915-22.

11. Kostek MC, Delmonico MJ, Reichel JB, Roth SM, Douglass L, Ferrell RE, et al. Muscle strength response to strength training is influenced by insulin-like growth factor 1 genotype in older adults. Journal of applied physiology (Bethesda, Md : 1985). 2005;98(6):2147-54.

12. He ZH, Hu Y, Li YC, Yvert T, Santiago C, Gomez-Gallego F, et al. Are calcineurin genes associated with athletic status? A function, replication study. Medicine and science in sports and exercise. 2011;43(8):1433-40.

13. He ZH, Hu Y, Wang HY, Li YC, Lu YL, Zhang L, et al. Are calcineurin genes associated with endurance phenotype traits? European journal of applied physiology. 2010;109(3):359-69.

14. Xi Y, Zhang D, G. W. Experimental study and evaluation of aerobic endurance training effect by running economy. Chinese Journal of Sports Medicine. 2008;27(1):15-9.

15. Bray MS, Hagberg JM, Perusse L, Rankinen T, Roth SM, Wolfarth B, et al. The human gene map for performance and health-related fitness phenotypes: the 2006-2007 update. Medicine and science in sports and exercise. 2009;41(1):35-73.

16. Olson EN, Williams RS. Calcineurin signaling and muscle remodeling. Cell. 2000;101(7):689-92.

17. Schaeffer PJ, Desantiago J, Yang J, Flagg TP, Kovacs A, Weinheimer CJ, et al. Impaired contractile function and calcium handling in hearts of cardiac-specific calcineurin b1-deficient mice. American journal of physiology Heart and circulatory physiology. 2009;297(4):H1263-73.

18. Graef IA, Chen F, Chen L, Kuo A, Crabtree GR. Signals transduced by $\mathrm{Ca}(2+) / \mathrm{calcineurin}$ and NFATc3/c4 pattern the developing vasculature. Cell. 2001;105(7):863-75.

19. Foster C, Lucia A. Running economy : the forgotten factor in elite performance. Sports medicine (Auckland, NZ). 2007;37(4-5):316-9.

20. Frey N, Barrientos T, Shelton JM, Frank D, Rutten H, Gehring D, et al. Mice lacking calsarcin-1 are sensitized to calcineurin signaling and show accelerated cardiomyopathy in response to pathological biomechanical stress. Nature medicine. 2004;10(12):1336-43.

21. da Costa N, Edgar J, Ooi PT, Su Y, Meissner JD, Chang KC. Calcineurin differentially regulates fast myosin heavy chain genes in oxidative muscle fibre type conversion. Cell and tissue research. 2007;329(3):515-27.

22. Ojuka EO, Goyaram V, Smith JA. The role of CaMKII in regulating GLUT4 expression in skeletal muscle. American journal of physiology Endocrinology and metabolism. 2012;303(3):E322-31.

23. De Moor MH, Spector TD, Cherkas LF, Falchi M, Hottenga JJ, Boomsma DI, et al. Genome-wide linkage scan for athlete status in 700 British female DZ twin pairs. Twin research and human genetics : the official journal of the International Society for Twin Studies. 2007;10(6):812-20.

24. Garcia-Roves PM, Huss J, Holloszy JO. Role of calcineurin in exercise-induced mitochondrial biogenesis. American journal of physiology Endocrinology and metabolism. 2006;290(6):E1172-9.

25. Hudson MB, Price SR. Calcineurin: a poorly understood regulator of muscle mass. The international journal of biochemistry \& cell biology. 2013;45(10):2173-8. 